\title{
LABOR MARKET TRENDS IN AKMOLA REGION OF KAZAKHSTAN
}

\author{
A.С. БЕЛЬГИБАЕВА* \\ к.э.Н., доцент \\ А.Ж. МУСИНА ${ }^{2}$ \\ К.Э.H. \\ М.А. ВОЛОХОВА \\ к.э.н. \\ ${ }^{1}$ Кокшетауский университет им. Ш.Уалиханова, Кокшетау, Казахстан \\ ${ }^{2}$ Торайгыров Университет, Павлодар, Казахстан \\ ${ }^{3}$ Поволжский научно-исследовательский институт экономики и организации \\ агропромышленного комплекса, Саратов, Россия \\ *электронная почта автора: anargul.belgibayeva@mail.ru \\ A.С. БЕЛЬГИБАЕВА* \\ э.Ғ.к., доцент \\ А.Ж. МУСИНА \\ э.ศ.K. \\ М.А. ВОЛОХОВА \\ Э.Ғ.К. \\ ${ }^{1}$ Ш.Уәлиханов атындағы Көкшетау университеті, Көкшетау, Қазақстан \\ ${ }^{2}$ Торайгыров Университеті, Павлодар, Қазақстан \\ ${ }^{3}$ Поволжье экономика және агроөнеркәсіптік кешенді ұйымдастыру ғылыми-зерттеу \\ институты, Саратов, Ресей \\ *автордың электрондық поштасы: anargul.belgibayeva@mail.ru

\section{A.S. BELGIBAYEVA*1} \\ C.E.Sc., Associate Professor \\ A.ZH. MUSSINA ${ }^{2}$ \\ C.E.SC. \\ M.A. VOLOKHOVA \\ C.E.SC. \\ 1 Sh. Ualikhanov Kokshetau University, Kokshetau, Kazakhstan \\ ${ }^{2}$ Toraighyrov University, Pavlodar, Kazakhstan \\ ${ }^{3}$ Volga Research Institute of Economics and Organization of Agro-Industrial Complex, \\ Saratov, Russia \\ *corresponding author e-mail: anargul.belgibayeva@mail.ru
}

Аннотация. Цель исследования заключается в рассмотрении основных тенденций и явлений, имеющих место на рынке труда в сельском хозяйстве. В процессе изучения данной проблемы выявлено, что большая часть занятого населения области проживает в сельской местности. Определено, что в настоящее время для сельского рынка труда характерны сокращение численности занятых в аграрном секторе экономики, ухудшение качественных параметров, характеризующих использование рабочей силы, несовпадение уровня компетенций специалистов с запросами расширенного воспроизводства и эффективностью трудовых ресурсов, нарастающая несбалансированность спроса и предложения квалифицированных работ-ников. Установлено, что в условиях безработицы, имеющей место на селе, среди жителей отмечено увеличение нехватки профессиональных кадров главных массовых специальностей в агропромышленном производстве. Проведён анализ структуры трудоустроенных в Акмолинской области, который показал значительные различия между занятостью в город-ской и сельской местности. Показана негативная тенденция, свя- 
занная с ростом удельного веса населения, возраст которого превышает трудоспособный, в общей численности жите-лей села. Сравнительный анализ отраслевой структуры сельской занятости показал сниже-ние доли занятых в сельском хозяйстве. В ходе исследования установлены основные причины перетока сельского населения в город. Указаны основные факторы, способствующие возвращению квалифицированных работников в аграрный сектор. Определены приоритетные направления трудообеспечения сельских жителей, наиболее важные из них - развитие малого и среднего предпринимательства на селе, а также самозанятости в личных хозяйствах населения. Предложен ряд мер, направленных на увеличение результативности функционирования рынка труда сельских территорий.

Аңдатпа. Зерттеудің мақсаты ауыл шаруашылығындағы еңбек нарығында орын алатын негізгі үрдістер мен құбылыстарды қарастыру болып табылады. Бұл мәселені зерттеу барысында облыстың жұмыспен қамтылған халқының басым бөлігі ауылдық жерлерде тұратыны анықталған. Қазіргі уақытта Ауыл еңбек нарығы үшін экономиканың аграрлық секторында жұмыспен қамтылғандар санының қысқаруы, жұмыс күшін пайдалануды сипаттайтын сапалық параметрлердің нашарлауы, мамандардың құзыреттері деңгейінің кеңейтілген ұдайы өндіріс сұраныстарымен және еңбек ресурстарының тиімділігімен сәйкес келмеуі, білікті қызметкерлердің сұранысы мен ұсынысының өсіп келе жатқан теңгерімсіздігі тән екендігі анықталған. Ауылда орын алған жұмыссыздық жағдайында тұрғындар арасында агроөнеркәсіптік өндірістегі басты бұқаралық мамандықтардың кәсіби кадрларының жетіспеушілігі байқалғаны анықталған. Ақмола облысында жұмыспен қамтылғандардың құрылымына талдау жүргізілді, ол қалалық және ауылдық жерлерде жұмыспен қамту арасындағы елеулі айырмашылықтарды көрсетті. Ауыл тұрғындарының жалпы санында еңбекке қабілетті жастан асқан халықтың үлес салмағының өсуіне байланысты теріс үрдіс көрсетілген. Ауылдық жұмыспен қамтудың салалық құрылымын салыстырмалы талдау ауыл шаруашылығында жұмыспен қамтылғандар үлесінің төмендегенін көрсетті. Зерттеу барысында ауыл халқының қалаға ағылуының негізгі себептері анықталған. Білікті жұмысшыларды аграрлық секторға қайтаруға ықпал ететін негізгі факторлар көрсетілген. Ауыл тұрғындарын еңбекпен қамтамасыз етудің басым бағыттары айқындалған, олардың ішіндегі неғұрлым маңыздылары - ауылда шағын және орта кәсіпкерлікті дамыту, сондай-ақ халықтың жеке шаруашылықтарында өзін-өзі жұмыспен қамту. Ауылдық аумақтардың еңбек нарығының жұмыс істеу нәтижелілігін арттыруға бағытталған бірқатар шаралар ұсынылған.

Abstract. The purpose of the study is to examine main trends and phenomena on labor market in agriculture. In the process of studying this problem, it was revealed that most of the employed population of the region lives in rural areas. It has been determined that at present the rural labor market is characterized by decrease in the number of employed in agricultural sector of economy, deterioration in the quality parameters characterizing the use of labor, discrepancy between the level of competence of specialists and the demands of expanded reproduction and efficiency of labor resources, and growing imbalance in the demand and supply of qualified workers. It has been determined that in conditions of unemployment in rural areas, the increased shortage of professional personnel in the main mass specialties in agro-industrial production has been noted among residents. The analysis of the structure of the employed in Akmola region was done, which showed significant differences between employment in urban and rural areas. A negative trend is shown which is associated with increase in proportion of the population, whose age exceeds the working age, in the total population of the village. Comparative analysis of sectoral structure of rural employment showed a decrease in the share of people who are employed in agriculture. In the course of the study, the main reasons for the rural population flow to the city have been determined. The main factors contributing to the return of skilled workers to agricultural sector are indicated. Priority areas of labor supply for rural residents have been identified, the most important of which are the development of small and medium-sized businesses in rural areas, as well as self-employment in private households. A number of measures aimed to increase the effectiveness of functioning of labor market in rural areas are proposed.

Ключевые слова: агропромышленный комплекс, рынок труда, Акмолинская область, занятость населения, отраслевая структура, трудовой потенциал, сельское население, кадры, социальная инфраструктура.

Түйінді сөздер: агроөнеркәсіптік кешен, еңбек нарығы, Ақмола облысы, халықты жұмыспен қамту, салалық құрылым, еңбек әлеуеті, ауыл халқы, кадрлар, әлеуметтік инфрақұрылым. 
Key words: agro-industrial complex, labor market, Akmola region, employment of the population, sectoral structure, labor potential, rural population, personnel, social infrastructure.

Введение. Особенно трудной проблемой в сфере сельскохозяйственного производства считается проблема создания и дальнейшего эфффективного функционирования рынка труда. Это объясняется переплетением интересов двух взаимосвязанных сторон: работодателя и работника.

Рынок труда - сорера фоормирования спроса и предложения на рабочую силу [1]. В последние годы занятость в сельской местности имеет тенденцию к снижению, при этом необходимо особо отметить фракт перемещения существенного количества жителей в трудоспособном возрасте из сельской местности в городскую.

Вопросы регулирования занятости сельского населения являются актуальной задачей не только на ближайшую, но и на отдаленную перспективу, так как сельское хозяйство представляет собой не только сореру производственной деятельности, но и является образом жизни большей части населения страны. Причинами стабильного снижения численности населения в сельской местности послужила, в первую очередь, естественная убыль, а также миграционный отток, вызванный низким уровнем жизни на селе, непривлекательностью имеющихся сфер приложения труда и социальной инфраструктуры и другими причинами.

В данное время рынку труда на селе присуща тенденция уменьшения количества занятых в сельскохозяйственном производстве при имеющем место параллельном перемещении работников в сферу услуг, ухудшение качественных параметров, характеризующих использование рабочей силы, несовпадение уровня компетенций специалистов с запросами рынка труда.

Цель исследования заключается в выявлении основных тенденций и явлений, имеющих место на рынке труда на селе, а также в определении направлений повышения занятости сельских жителей.
Материал и методы исследования. Теоретической и методологической базой исследования послужили работы в сфрере экономики труда, в которых обозначены особенности формирования и применения потенциала рабочей силы в регионах, а также определена суть организации региональных и отраслевых рынков труда и выявлены факторы, оказывающие влияние на становление и функционирование этих рынков.

В процессе работы над публикацией были использованы следующие методы исследований: экономико-статистический при оценке основных тенденций рынка труда Акмолинской области, для осуществления количественного и качественного анализа используемых показателей, выяснения наиболее важных категорий, которые дают в полном объеме статистическую и аналитическую информацию о состоянии и перспективах развития рынка труда на сельских территориях; абстрактно-логический - при определении и обозначении проблем, связанных с рациональным использованием трудовых ресурсов на селе; аналитический - при выявлении тенденций государственной поддержки занятости, при определении основных фракторов, оказывающих влияние на повышение занятости сельского населения. Для анализа рынка труда сельских территорий были рассмотрены в динамике такие индикаторы, как уровень занятости и безработицы, структура секторальной, возрастной и отраслевой занятости.

Результаты и их обсуждение. В настоящее время наряду с необходимостью поддержки занятости сельских жителей одной из существенных проблем высокоэффективного функционирования рынка труда на сельских территориях является также и сокращение уровня безработицы. В таблице 1 приведены основные характеристики рабочей силы в области.

Таблица 1 - Основные характеристики рабочей силы в Акмолинской области, 2017-2019 гг.

\begin{tabular}{|c|c|c|c|c|c|c|c|}
\hline \multirow{3}{*}{ Год } & \multicolumn{5}{|c|}{ Численность, тыс.чел. } & \multirow{3}{*}{$\begin{array}{c}\text { Уровень } \\
\text { участия в } \\
\text { рабочей } \\
\text { силе, \% }\end{array}$} & \multirow{3}{*}{\begin{tabular}{|c|} 
Уровень \\
занято- \\
сти, \%
\end{tabular}} \\
\hline & \multirow{2}{*}{$\begin{array}{c}\text { население в } \\
\text { возрасте } 15 \\
\text { лет и старше }\end{array}$} & \multirow{2}{*}{$\begin{array}{c}\text { рабочая } \\
\text { сила }\end{array}$} & \multicolumn{2}{|c|}{ В том числе } & \multirow{2}{*}{$\begin{array}{c}\text { лица, не входя- } \\
\text { щие в состав } \\
\text { рабочей силы }\end{array}$} & & \\
\hline & & & $\begin{array}{c}\text { заня- } \\
\text { тые }\end{array}$ & $\begin{array}{l}\text { безра- } \\
\text { ботные }\end{array}$ & & & \\
\hline 2017 & 562,0 & 428,9 & 408,3 & 20,6 & 133,1 & 76,3 & 72,6 \\
\hline 2018 & 564,1 & 429,2 & 409,0 & 20,5 & 134,9 & 76,1 & 72,4 \\
\hline 2019 & 563,0 & 428,3 & 408,0 & 20,3 & 134,8 & 76,1 & 72,5 \\
\hline
\end{tabular}


В 2019г. численность экономически активного населения области составила 428,3 тыс. человек. В численности экономически активного населения 408,0 тыс. чел. - это занятые экономической деятельностью, 20,3 тыс. чел. - безработные.

Уровень занятости населения имеет нисходящую динамику, показатель в 2019г. сократился до 76,1\% (в 2017г. - 76,3\%).

Изменение степени занятости населения можно объяснить разными причинами, в том числе как демографическими, так и экономическими [2].

Под занятостью населения понимается трудовая деятельность, связанная с удовлетворением личных и общественных по- требностей, не противоречащая законодательству Республики Казахстан, приносящая заработок или доход [см.1].

В республике основная часть занятого населения проживает в городской местности (58,4\% или 8 780,8 тыс. человек в 2019г.). В Акмолинской области удельный вес занятого населения, проживающего в городской местности, составил в 2019г. $47,6 \%$, т.е. большая часть населения проживает в сельской местности $(52,4 \%$, или 214,0 тыс. человек) [3].

В структуре занятого населения Акмолинской области существуют значительные различия между городской и сельской местностью (таблица 2).

Таблица 2 - Занятое население Акмолинской области по статусу занятости, \%

\begin{tabular}{|c|c|c|c|c|c|c|}
\hline \multirow[b]{3}{*}{ Показатель } & \multicolumn{3}{|c|}{ 2017r. } & \multicolumn{3}{|c|}{$2019 r}$. \\
\hline & \multirow[t]{2}{*}{ всего } & \multicolumn{2}{|c|}{ в том числе } & \multirow[t]{2}{*}{ всего } & \multicolumn{2}{|c|}{ в том числе } \\
\hline & & $\begin{array}{c}\text { в город- } \\
\text { ской мест- } \\
\text { ности }\end{array}$ & $\begin{array}{l}\text { в сель- } \\
\text { ской ме- } \\
\text { стности }\end{array}$ & & $\begin{array}{c}\text { в город- } \\
\text { ской мест- } \\
\text { ности }\end{array}$ & $\begin{array}{c}\text { в сель- } \\
\text { ской мест- } \\
\text { ности }\end{array}$ \\
\hline Занятое население & 100 & 47,9 & 52,1 & 100 & 47,6 & 52,4 \\
\hline Наемные работники & 65,8 & 74,5 & 57,9 & 68,0 & 75,6 & 61,1 \\
\hline \multicolumn{7}{|l|}{ в т.ч. заняты: } \\
\hline - по найму в организации & 85,1 & 85.0 & 85,1 & 85,4 & 85,7 & 85,0 \\
\hline $\begin{array}{l}\text { - по найму у фризических } \\
\text { лиц }\end{array}$ & 12,1 & 14,7 & 9,0 & 11,3 & 13,6 & 8,7 \\
\hline - в крестьянском хозяйстве & 2,9 & 0,3 & 5,9 & 3,3 & 0,6 & 6,3 \\
\hline $\begin{array}{l}\text { - по договору гражданско- } \\
\text { правового характера на } \\
\text { оказание услуг }\end{array}$ & - & - & - & 0,03 & 0,04 & 0,03 \\
\hline $\begin{array}{l}\text { Самостоятельно занятые } \\
\text { работники }\end{array}$ & 34,2 & 25,5 & 42,1 & 32,0 & 24,4 & 38,9 \\
\hline
\end{tabular}

В целом в области наблюдается увели-чение удельного веса наемных работников в структуре занятого населения с $65,8 \%$ в 2017г. до $68 \%$ в 2019г. при одновременном сокращении удельного веса самостоятельно занятого населения с $34,2 \%$ до $32 \%$. Эта тенденция характерна как для жителей, занятых в городе, так и для жителей, занятых на сельских территориях.

В городе доля наемных работников в структуре всего занятого населения составляет $75,6 \%$, а доля самостоятельно занятых - 24,4\%. В сельской же местности доля самостоятельно занятых превышает значение этого показателя в городе. Так, на селе $61,1 \%$ занятого населения - это наемные работники, а $38,9 \%$ - самостоятельно занятые.
Доля самостоятельно занятых в сельской местности превышает значение этого показателя в городской местности в большей степени по причине отсутствия у сельских жителей альтернативы, недостатка квалификации и дефицита рабочих мест.

Важным показателем уровня экономического развития региона и страны является отраслевая структура занятости населения. На рисунке представлена структура занятого населения Акмолинской области по видам экономической деятельности в 2019 году.

$52,4 \%$ (214,0 тыс. человек) занятого населения в 2019г. в Акмолинской области проживало в сельской местности. 


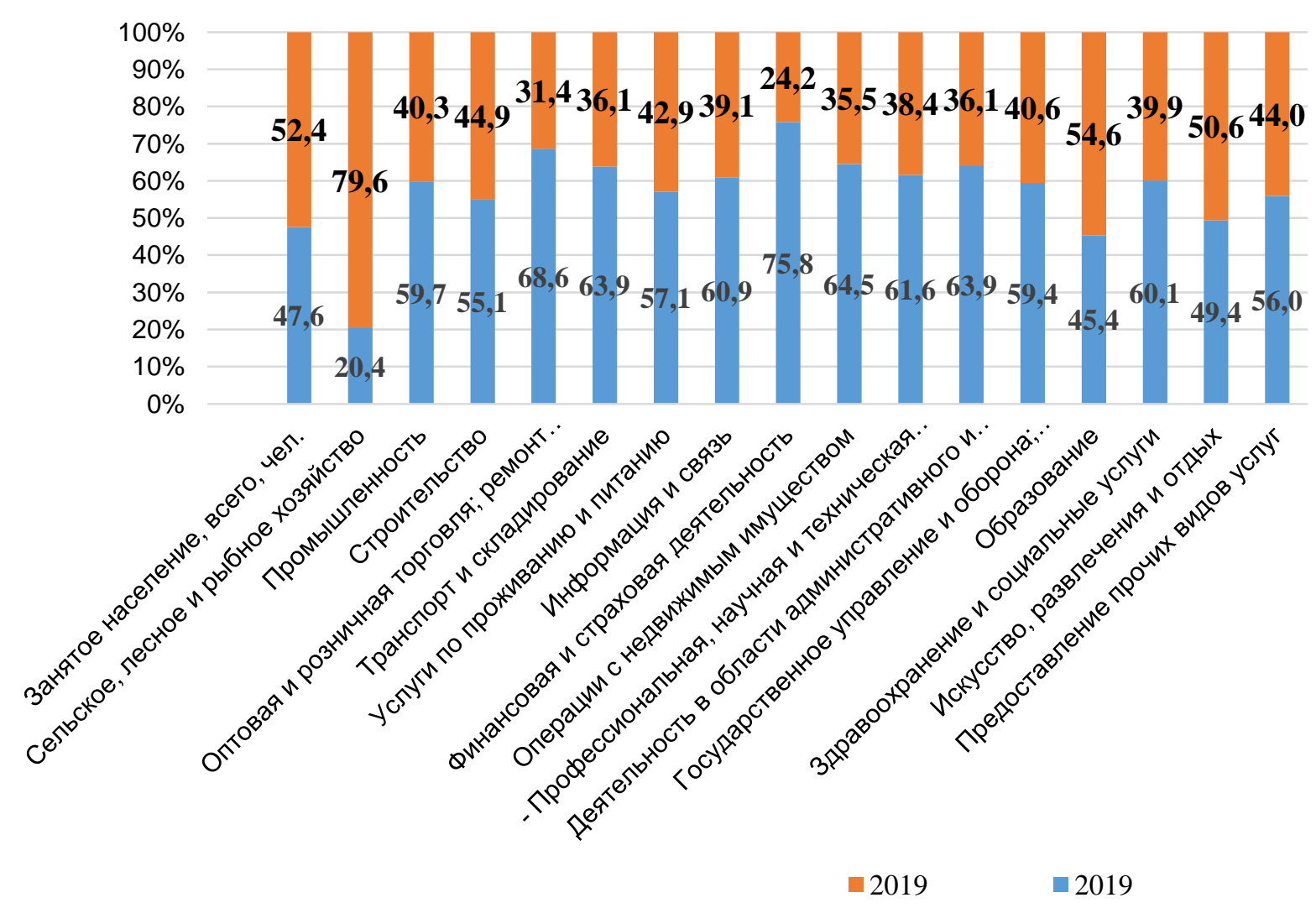

Примечание: составлен авторами по данным Бюро национальной статистики Агентства по стратегическому планированию и реформам Республики Казахстан, 2019 г.

\section{Рисунок - Структура занятого населения Акмолинской области по видам экономической деятельности в 2019г., \%}

Основной сферой приложения труда для $29 \%$ всего занятого населения области (118,2 тыс. чел.) является отрасль сельского хозяйства. В сельской местности проживает 79,6\% (94,1 тыс. чел.), занятых в этой отрасли, а в городской местности $20,4 \%$ (24,1 тыс. чел.). Также в сельской местности проживает $54,6 \%$ населения, занятого в образовании; 50,6\% населения, занятого в сорере развлечений и отдыха; $44,9 \%$ населения, занятого в строительстве; $42,9 \%$ населения, занятого в сфере услуг по проживанию и питанию; 40,3\% населения, занятого в промышленности.

За анализируемый период наблюдается рост численности занятого населения в сельской местности на 1207 человек (с 212780 в 2017г. до 213987 человек в 2019г.). При этом в структуре занятого населения по видам экономической деятельности произошли изменения в сторону сокращения численности населения, занятого в сельском хозяйстве на 8879 человек (с 102943 в 2017г. до 94064 чел. в 2019г.).

Отрасль сельского хозяйства понесла существенные потери, так как удельный вес занятых в сельском хозяйстве в общем количестве занятых снизился с 48,4\% в 2017г. до 44\% в 2019году. Основными же генераторами рабочих мест стали: промышленность $(+0,6 \%)$, оптовая и розничная торговля $(+0,9 \%)$.

Наименьший уровень занятости в сельской местности отмечен в сфере фринансовой и страховой деятельности $(0,5 \%)$, информации и связи $(0,7 \%)$, операций с недвижимым имуществом $(0,9 \%)$, а также профессиональной, научной и технической деятельности $(0,9 \%)$.

Таким образом, структура занятости на селе в отраслевом разрезе в области претерпевает определенные изменения. Ключевыми трендами стали снижение доли занятых в сельском хозяйстве, а также рост доли занятых в сферах промышленности, оптовой и розничной торговли.

Исходя из вышеизложенного, можем утверждать, что снижение занятости в аграрном секторе экономики неизбежный процесс, который возможно будет компенсировать одновременным ростом занятости в несельскохозяйственных сфрерах экономики. 
В последние годы все больше проявляются последствия структурных демографичческих преобразований, старение и сокращение доли трудоспособного населения. Так, в настоящее время аграрные предприятия области столкнулись с проблемой старения кадров вследствие сла- бого притока молодых специалистов, что ведет к трудно-восполнимым потерям трудоспособного населения на селе.

В таблице 3 представлена структура сельского населения области согласно основных возрастных групп.

Таблица 3 - Структура сельского населения Акмолинской области по основным возрастным группам, \%

\begin{tabular}{|l|c|c|c|c|c|c|c|c|c|}
\hline \multirow{2}{*}{$\begin{array}{l}\text { Основные возрас- } \\
\text { тные группы }\end{array}$} & \multicolumn{3}{|c|}{2017 г. } & \multicolumn{3}{|c|}{2018 г. } & \multicolumn{3}{c|}{2019 г. } \\
\cline { 2 - 11 } \\
\hline $\begin{array}{l}\text { Моложе трудоспо- } \\
\text { собного возраста }\end{array}$ & 23,1 & 23,8 & 22,5 & 23,3 & 24,1 & 22,6 & 23,1 & 23,8 & 22,4 \\
\hline $\begin{array}{l}\text { Трудоспособного } \\
\text { возраста }\end{array}$ & 67,1 & 68,6 & 65,7 & 66,6 & 67,8 & 65,5 & 66,1 & 67,6 & 64,7 \\
\hline $\begin{array}{l}\text { Старше трудоспо- } \\
\text { собного возраста }\end{array}$ & 9,7 & 7,6 & 11,9 & 10,1 & 8,2 & 11,9 & 10,7 & 8,6 & 12,9 \\
\hline
\end{tabular}

Примечание: составлена авторами по данным Бюро национальной статистики Агентства по стратегическому планированию и рефоормам Республики Казахстан, 2017-2019 годы.

Основную долю в структуре жителей села по основным возрастным категориям занимает население трудоспособного возраста, удельный вес которого снизился с $67,1 \%$ в 2017г. до $66,1 \%$ в 2019 году. Наблюдается негативная тенденция, связанная с увеличением в структуре жителей села удельного веса жителей, возраст которых превышает трудоспособный (с 9,7\% в 2017г. до 10,7\% в 2019г.). Эта тенденция ха-рактерна как для мужского, так и женского населения области.

По мнению многих авторов отток молодых специалистов из сельской местности связан с низким уровнем заработной платы и недостаточным уровнем социально-культурно-бытовых условий на селе [4]. Также помимо невысокой заработной платы, недостаточного социально-экономического уровня развития сельских территорий, способствующего миграции молодежи из села, усугубляют ситуацию сложные условия труда, призрачные перспективы карьерного роста.

Возвращению молодых специалистов в аграрную сферу будут способствовать такие основные фракторы, как высокая заработная плата, предоставление жилья на праве собственности, наличие развитой инфраструктуры на селе, которые должны быть положены в основу политики государства по возрождению села и обеспечению занятости жителей на сельских территориях [5].

Исходя из расположения кривых, на ко-торых отображены возрастные группы сель-ских жителей, можем отметить крайне неже-лательную тенденцию. Доля сельских жителей, которые находятся в трудоспособном возрасте, имеет устойчивую тенденцию к снижению (с 67,1\% в 2017г. до $66,1 \%$ в 2019г.), а доля сельских жителей, возраст которых старше трудоспособного, увеличилась с 9,7\% в 2017 г. до 10,7\% в 2019 году. Увеличение количества сельских жителей, возраст которых превышает трудоспособный, за анализируемый период составило 4,5 тыс. человек. При этом число сельских жителей в возрасте моложе трудоспособного изменилось несущественно.

За период с 2017 по 2019г. заметно улучшение состава рабочей силы по уровню образования на селе (таблица 4).

Можно отметить рост численности населения, имеющего высшее, незаконченное высшее, среднее профессиональное и на-чальное профессиональное образование (на $10,6 \%, 26,7 \%, 13,2 \%$ и 3,9\%, соответственно). На воспроизводство и полноту использования рабочей силы на селе немаловажное влияние оказывает и гендерный состав жителей [6].

На селе удельный вес женщин в структуре населения трудоспособного возраста преобладает над мужским населением и держится в течение анализируемого периода на уровне $50,7 \%$. Количество женского населения в трудоспособном возрасте в Акмолинской области превосходит мужское население после 45-летнего возраста и достигает максимальной разницы (в количестве 8,6 тыс.чел.) в возрасте старше 65 лет. 
Таблица 4 - Рабочая сила по уровню образованности в сельской местности в Акмолинской области, тыс. человек (2017-2019гг.)

\begin{tabular}{|l|r|r|r|r|r|r|c|}
\hline \multicolumn{1}{|c|}{ Показатель } & \multicolumn{2}{|c|}{2017 г. } & \multicolumn{2}{c|}{ 2018г. } & \multicolumn{2}{c|}{ 2019г. } & $\begin{array}{c}\text { 2019г. к } \\
\text { 2017г., \% }\end{array}$ \\
\hline Рабочая сила, всего & 224,5 & 100 & 225,6 & 100 & 225,5 & 100 & 100,4 \\
\hline из них имеют образование: & & & & & & & \\
\hline - высшее & 50,9 & 22,7 & 58,4 & 25,9 & 56,3 & 25,0 & 110,6 \\
\hline - незаконченное высшее & 2,5 & 1,1 & 3,4 & 1,5 & 3,1 & 1,4 & 126,7 \\
\hline - среднее профессиональное & 90,6 & 40,3 & 88,5 & 39,2 & 102,5 & 45,5 & 113,2 \\
\hline - начальное профессиональное & 9,7 & 4,3 & 11,9 & 5,3 & 10,0 & 4,5 & 103,9 \\
\hline - среднее общее & 50,7 & 22,6 & 52,6 & 23,3 & 45,6 & 20,2 & 90,1 \\
\hline - основное среднее & 18,7 & 8,3 & 10,0 & 4,4 & 7,6 & 3,3 & 40,5 \\
\hline - начальное & 1,6 & 0,7 & 0,9 & 0,4 & 0,4 & 0,2 & 22,1 \\
\hline
\end{tabular}

Примечание: составлена авторами по данным Бюро национальной статистики Агентства по стратегическому планированию и ресрормам Республики Казахстан, 2017-2019 годы.

Дефицит квалифицированных специалистов в аграрном секторе характерен практически для всех областей и регионов страны. Наблюдается сокращение удельного веса специалистов в наиболее активной возрастной группе (от 30 до 50 лет). Несмотря на тот фракт, что уровень безработицы в сельской местности превышает уровень безработицы в городе, актуальной проблемой для многих предприятий аграрной сферы области остается десрицит квалифицированных кадров.

Существование этой проблемы можно объяснить низкой мотивацией к труду в аграрном секторе высококвалифицированных специалистов по причине низкой оплаты труда, ограниченного доступа к социально-бытовым благам и др. Все это подталкивает их к переходу на более высокооплачиваемую работу в несельскохозяйственном производстве и к переезду в городскую местность [7].

В связи с вышеизложенным, решение проблемы дефицита квалифицированных специалистов на предприятиях аграрного сектора возможно только при комплексном воздействии на все сферы жизнедеятельности сельского населения, в том числе путем повышения престижности труда в сельскохозяйственном производстве [см.5].

Повышение кадрового потенциала в сельской местности предусматривает государственную поддержку специалистов социальной сферы и АПК, прибывших для ра-боты и проживания в сельской местности, в виде выплаты подъемного пособия и предоставления бюджетного кредита на приобретение или строительство жилья [8].

В стране в настоящее время реализуется ряд программ и мероприятий, которые направлены на улучшение качества жизни на селе, на модернизацию социальной среды $[9,10]$.

Таким образом, совокупность всех реализуемых в стране программ и мероприятий в сорере занятости должна быть направлена на решение первоочередной задачи - обеспечение повышения эффрективности функционирования рынка труда на селе с целью снижения социальной напряженности, связанной с наличием большого числа незанятых трудоспособных сельских жителей.

В настоящее время приоритетным направлением обеспечения занятости сельского населения является развитие малого и среднего предпринимательства в несельскохозяйственной сфрере, способствующее диверсификации хозяйственной деятельно-сти сельских жителей, расширению источ-ников пополнения семейного бюджета и масштабов занятости сельского населения, а также повышению уровня жизни сельского населения.

\section{Заключение}

1. За анализируемый период наблюдается рост численности занятого населения в сельской местности на 1207 человек (с 212780 в 2017г. до 213987 человек в 2019г.). В области удельный вес занятого населения, проживающего в сельской местности, составил в 2019г. 52,4\%.

2. Рынку труда в сельской местности характерно сокращение численности жителей, занятых в сельскохозяйственном производстве. За анализируемый период выяв-лены изменения в сторону уменьшения чис-ленности жителей, занятых в аграрной сорере на 8879 человек (с 102943 в 2017г. до 94064 человек в 2019г.).

3. Предложение более высокооплачиваемых рабочих мест в не аграрном секторе ведет к уходу работника в несельскохо- 
зяйственную занятость. Существующее мнение о жителях села как работниках в основном сельскохозяйственного производства в настоящее время не актуально.

4. Основную долю в структуре сельского населения по основным возрастным группам занимает население трудоспособного возраста. Наблюдается негативная тенденция, связанная с увеличением в структуре сельского населения удельного веса жителей, возраст которых превышает трудоспособный.

5. Среди населения трудоспособного возраста, проживающего на сельских территориях области, доля женского населения преобладает. Количество женского населения в трудоспособном возрасте в Акмолинской области превосходит мужское население после 45-летнего возраста и достигает максимальной разницы (в количестве 8,6 тыс.чел.) в возрасте старше 65 лет.

6. Для решения проблемы нехватки квалифицированных специалистов на предприятиях аграрного сектора необходимо совокупное воздействие на все сферы жизнедеятельности сельских жителей, в том числе путем повышения престижа сельскохозяйственного труда. Приоритетным направлением обеспечения занятости сельского населения является развитие малого и среднего предпринимательства в несельскохозяйственной сфере.

\section{Список литературы}

[1] О занятости населения. Закон Республики Казахстан от 6 апреля 2016 года № 482-V ЗРК [Электронный ресурс].-2016.-URL: http://adilet.zan.kz/rus/docs/Z1600000482 (дата обращения: 10.01.2021).

[2] Антонов, Е.В. Динамика занятости и состояния рынков труда регионов России в 2010-2017 гг. / Е.В. Антонов // Вестник Санкт-Петербургского университета. Науки о Земле.- 2019.- №64(4).- C.559-574 https:// doi.org/10.21638/spbu07.2019.404.

[3] Основные индикаторы рынка труда в Республике Казахстан (4 части) [Электронный ресурс].-2019.-URL: https://stat.gov.kz (дата обращения: 12.01.2021).

[4] Ибришев, Н.Н. Анализ качества жизнедеятельности сельского населения Республики Казахстан / Н.Н. Ибришев, А.Б. Молдашев, С.Т.Жумашева, И.С.Таипова //Проблемы агрорынка.-2018.-№3.-С.186-192.

[5] Волков, В.И. Обеспечение квалифицированными кадрами предприятий аграрной сферы агропромышленного комплекса региона / В.И. Волков, В.И. Набоков, Н.К. Юлдашев // Аграрный вестник Урала.-2020.-№ 06 (197).-C.81-88.
[6] Лещева, М.Г. Кадровый потенциал сельскохозяйственных организаций региона: формирование и использование / М.Г. Лещева//Известия ТСХА.-2017.-Вып. 6.- С.114-128.

[7] Об утверждении Государственной программы развития агропромышленного комплекса Республики Казахстан на 20172021 годы. Постановление Правительства Республики Казахстан от 12 июля 2018 года № 423 [Электронный ресурс].- 2018.- URL: http://adilet.zan.kz/rus/docs/P1800000423 (дата обращения: 10.01.2021).

[8] Об утверждении Государственной программы развития регионов на 2020 - 2025 годы. Постановление Правительства Республики Казахстан от 27 декабря 2019 года № 990 [Электронный ресурс].- 2019.- URL: http:// adilet.zan.kz/rus/docs/P1900000990 (дата обращения: 15.01.2021).

[9] Повышение качества жизни на селе: проектом «Ауыл - Ел бесігі» до 2025 года будут охвачены 80\% всех сельских жителей [Электронный ресурc].- 2019.- URL: https:// primeminister.kz/ru/povishenie-kachestva-zhiznina-sele-proektom-auil-el-besigi-do- 2025- godabudut-ohvacheni-80-vseh-selskih-zhitelei (дата обращения: 16.01.2021).

[10] Об утверждении Государственной программы развития продуктивной занятости и массового предпринимательства на 20172021 годы "Еңбек". Постановление Правительства Республики Казахстан от 13 ноября 2018 года №746 [Электронный ресурс].-2018.URL: http://adilet.zan.kz/rus/docs/P1800000746 (дата обращения: 22.01.2021)

\section{References}

[1] On employment of the population. Law of the Republic of Kazakhstan dated April 6, 2016 No. 482-V LRK [Electronic resource].2016.- URL: http://adilet.zan.kz/rus/docs/Z16000 00482 (date of access: 10.01.2021).

[2] Antonov, E.V. Dynamics of employment and state of labor markets in regions of Russia in 2010-2017. / E.V. Antonov // Bulletin of St. Petersburg University. Earth Sciences.-2019.№64(4).- PP.559-574 https://doi.org/10.21638/ spbu07.2019.404.

3] Main indicators of labor market in the Republic of Kazakhstan (4 parts) [Electronic resource].- 2019.-URL: https://stat.gov.kz (date of access: 12.01.2021).

[4] Ibrishev, N.N. Analysis of the life quality of the rural population of the Republic of $\mathrm{Ka}$ zakhstan / N.N. Ibrishev, A.B.Moldashev, S.T. Zhumasheva, I.S. Taipova // Problems of Agri Market.-2018.-No.3.-PP.186-192.

[5] Volkov, V.I. Provision of qualified personnel for enterprises of agricultural sector of agro-industrial complex of the region / V.I. Volkov, V.I. Nabokov, N.K. Yuldashev // Agrari- 
an Bulletin of the Urals. -2020.-№ 06 (197).PP.81-88.

[6] Leshcheva, M.G. Personnel potential of agricultural organizations in the region: formation and use / M.G. Leshcheva // Izvestiya TAA. -2017.- Issue 6.- PP. 114-128.

[7] On approval of the State program on development of agro-industrial complex of the Republic of Kazakhstan for 2017-2021. Resolution of the Government of the Republic of Kazakhstan dated July 12, 2018 No. 423 [Electronic resource].-2018.-URL: http://adilet.zan.kz/ rus/ docs/P180000423 (date of access: 10.01.2021).

[8] On the approval of the State Program on Regional Development for 2020 - 2025. Decree of the Government of the Republic of Kazakhstan dated December 27, 2019 No.990 [Electronic resource].- 2019.-URL: http://adilet.zan.kz/ rus/ docs/P1900000990 (date of access: 15.01.2021).

[9] Improvement of life quality in the countryside: the project "Auyl - El besigi" by 2025 will cover $80 \%$ of all rural residents [Electronic resource].- 2019.-URL: https://primeminister.kz/ ru/povishenie- kachestva -zhizni- na-sele-proektom- auil- el- besigi-do-2025-goda-budut-ohvacheni-80-vseh-selskih-zhitelei (date of access: 16.01.2021).

[10] On the approval of the State Program on Development of Productive Employment and Mass Entrepreneurship for 2017-2021 "Enbek". Resolution of the Government of the Republic of Kazakhstan dated November 13, 2018 No. 746 [Electronic resource].-2018.-URL: http://adilet. zan. kz/ rus/docs/P1800000746 (date of access: 22.01.2021).

\section{Информация об авторах:}

Бельгибаева Анаргуль Сарсенбаевна; кандидат экономических наук, доцент; профессор кафедры «Экономика и учет»; Кокшетауский университет им. Ш.Уалиханова; г.Кокшетау, 020000 ул.Абая 76, Казахстан; anargul.belgibayeva@mail.ru; https://orcid.org/0000-0001-5583-0624

Мусина Алма Жумагельдыевна; кандидат экономических наук; заведующая кафедрой «Финансы и учет»; Торайгыров Университет; г.Павлодар, 140008 ул.Ломова 64, Казахстан; alma1404@ yandex.ru; https://orcid.org/0000-0002-3893-316X

Волохова Марина Александровна; кандидат экономических наук; старший научный сотрудник; Поволжский научно-исследовательский институт экономики и организации агропромышленного комплекса; г.Саратов, 410010 ул. Шехурдина 12, Россия; nii_apk_sar@mail.ru; https://orcid.org/00000002-2559-8948

\section{Авторлар туралы ақпарат:}

Бельгибаева Анаргуль Сарсенбаевна; экономика ғылымдарының кандидаты, доцент; «Экономика және есеп» кафедрасының профессоры; Ш.Уәлиханов атындағы Көкшетау университеті; Көкшетау қ., 020000 Абай көшесі 76, Қазақстан; anargul.belgibayeva@mail.ru; https:// orcid.org/ 0000-0001-5583-0624

Мусина Алма Жумагельдыевна; экономика ғылымдарының кандидаты; «Қаржы және есеп» кафедрасының меңгерушісі»; Торайгыров Университеті; Павлодар қ., 140008 Ломов көшесі 64, Қазақстан; alma1404@yandex.ru; https://orcid.org/0000-0002-3893-316X

Волохова Марина Александровна; экономика ғылымдарының кандидаты; аға ғылыми қызметкер; Поволжье экономика және агроөнеркәсіптік кешенді ұйымдастыру ғылыми-зерттеу институты; Саратов қ., 410010 Шехурдин көшесі 12, Ресей; nii_apk_sar@mail.ru; https://orcid.org/ 0000-0002-2559-8948

\section{Information about authors:}

Belgibayeva Anargul Sarsenbayevna; Candidate of Economic Sciences, Associated Professor; Professor of the Department of Economics and Accounting; Sh. Ualikhanov Kokshetau University; Kokshetau, 020000 Abay str. 76, Kazakhstan; anargul.belgibayeva@mail.ru; https://orcid.org/0000-00015583-0624

Mussina Alma Zhumageldyevna; Candidate of Economic Sciences; Head of the Department of Finance and Accounting; Toraighyrov University; Pavlodar, 140008 Lomova str. 64, Kazakhstan; alma1404@yandex.ru; https://orcid.org/0000-0002-3893-316X

Volokhova Marina; Candidate of Economic Sciences; Senior Researcher; Volga Research Institute of Economics and Organization of Agro-Industrial Complex; Saratov, 410010 Shekhurdina str. 12, Russia; nii_apk_sar@mail.ru; https://orcid.org/0000-0002-2559-8948 